\title{
Pemberian minuman formula kacang merah, kacang tanah, dan kacang kedelai terhadap status gizi ibu hamil kurang energi kronis (KEK) ${ }^{1}$
}

The influence of red beans, peanuts, and soybeans drink formula towards the nutritional status of pregnant women with chronic energy deficiency (CED)

\author{
Nendhi Wahyunia Utami², Tita Husnitawati Majid ${ }^{3}$, Dewi Marhaeni Diah Herawati ${ }^{4}$ \\ ${ }^{2}$ Magister Kebidanan, Fakultas Kedokteran Universitas Padjadjaran \\ ${ }^{3}$ Departemen Obstetri dan Ginekologi, Fakultas Kedokteran Universitas Padjadjaran \\ ${ }^{4}$ Departemen Gizi Medik Ilmu Kesehatan Masyarakat, Fakultas Kedokteran Universitas Padjadjaran
}

\begin{abstract}
Background: The prevalence of malnutrition in pregnant women DIY reached $22.69 \%$, while at Sleman amounted to $11.72 \%$. The study has been developed drinks formula derived from beans that contain the nutrient according to the needs of pregnant women. Objective: This study aimed to analyze the influence of red beans, peanuts and soybeans drink formula against the nutritional status of pregnant women. Method: The study design is randomized controlled trial (RCT). The inclusion criteria are pregnant women with chronic energy deficiency and gestational age between 14-28 weeks. The research locations in 8 health centers in Sleman with total sample of 84 people. Data obtained by measuring LILA and pregnant women weight before and after being given a drink formula. Data analysis using Chi-Square, paired t-test and Wilcoxon. Results: There was differences between the increase of weight and LILA pregnant women in the treatment group was higher than controls $(p<0.005)$. Increase of BB and LILA on the three groups there is a difference ( $p<0.001)$. Based on measurements of nutritional status of pregnant women showed that significant effect giving peanuts formula compared to red beans and soybean formula that does not significantly $(p<0.001)$. Groups of pregnant women who get peanuts formula showed increased protein intake above the standard of $67 \mathrm{~g}$ and a total energy of 2260 calorie. Conclusion: Nutritional status of pregnant women who get the peanut formula higher than by red beans, soybeans, and formula for pregnant women. Pregnant women who received peanuts formula have higher energy and protein intake than the other formulas.
\end{abstract}

KEYWORDS: drinks formula; nutritional status; peanuts; pregnant women; red beans; soybeans

\begin{abstract}
ABSTRAK
Latar belakang: Prevalensi ibu hamil yang mengalami Kurang Energi Kronik (KEK) di Daerah Istimewa Yogyakarta (DIY) mencapai 22,69\% sedangkan di Kabupaten Sleman sebesar 11,72\%. Diduga minuman yang berasal dari sumber nabati kacangkacangan dapat meningkatkan status gizi ibu hamil KEK. Tujuan: Mengetahui pengaruh pemberian minuman formula kacang merah, kacang tanah, dan kacang kedelai terhadap status gizi ibu hamil. Metode: Penelitian dengan rancangan open labeled randomized controlled trial (RCT) di wilayah Kabupaten Sleman pada bulan Januari-Maret 2016. Subjek yaitu ibu hamil gizi kurang dengan usia kehamilan 14-28 minggu yang memenuhi kriteria inklusi dan eksklusi sebanyak 84 ibu hamil. Pengukuran lingkar lengan atas (LILA) dan indeks massa tubuh (IMT) ibu hamil dilakukan sebelum dan setelah diberikan minuman formula. Hasil: Tidak terdapat perbedaan IMT antara kelompok perlakuan dan kontrol sebelum dan setelah intervensi. Terdapat peningkatan berat badan (BB) dan LILA ibu hamil antarkelompok dan peningkatan kelompok perlakuan lebih tinggi dibandingkan kontrol ( $p<0,005)$. Kelompok formula kacang tanah memiliki peningkatan status gizi lebih tinggi dibandingkan kelompok lainnya. Kelompok formula kacang tanah juga menunjukkan peningkatan asupan protein dan energi di atas angka kecukupan dibandingkan kelompok lain. Simpulan: Status gizi ibu hamil yang mendapatkan formula kacang tanah lebih tinggi dibandingkan pemberian kacang merah, kacang kedelai, dan susu formula ibu hamil. Asupan energi dan protein lebih tinggi pada ibu hamil yang mendapatkan formula kacang tanah.
\end{abstract}

KATA KUNCI: minuman formula; status gizi; kacang tanah; ibu hamil; kacang merah; kacang kedelai

${ }^{1}$ Dipresentasikan pada $7^{\text {th }}$ International Symposium on Wellness, Healthy Lifestyle and Nutrition pada tanggal 3-4 November 2016 di Yogyakarta yang diselenggarakan oleh Departemen Gizi Kesehatan, Fakultas Kedokteran Universitas Gadjah Mada, Indonesia kerjasama dengan Universiti Sains Malaysia, Malaysia dan Prince of Songkla University, Thailand

Korespondensi: Nendhi Wahyunia Utami, Magister Kebidanan, Fakultas Kedokteran Universitas Padjadjaran, Jl. Raya Bandung Sumedang KM 21, Jatinangor, Hegarmanah, Jatinangor, Kabupaten Sumedang, Jawa Barat 45363, e-mail: nendynia@gmail.com 


\section{PENDAHULUAN}

Status gizi ibu menjadi salah satu faktor yang menentukan pertumbuhan dan perkembangan janin termasuk berat dan panjang saat lahir. Berat dan panjang lahir menentukan status gizi dan pertumbuhan linier anak di masa mendatang. Gizi ibu yang buruk sebelum maupun pada saat kehamilan dapat menyebabkan pertumbuhan janin terhambat, bayi lahir dengan berat lahir rendah (BBLR), gangguan perkembangan dan pertumbuhan otak bayi serta meningkatkan risiko kesakitan dan kematian bayi. Disebutkan bahwa tingginya jumlah gizi kurang dan gizi buruk di Indonesia memiliki kolerasi dengan tingginya tingkat kemiskinan di Indonesia (1-4). Kemiskinan dan kurang gizi merupakan suatu fenomena yang saling terkait, oleh karena itu meningkatkan status gizi suatu masyarakat erat kaitannya dengan upaya peningkatan ekonomi. Masyarakat miskin memiliki kemampuan yang sangat rendah untuk memenuhi pangan yang dibutuhkan dalam jumlah dan kualitas yang memadai (5).

Dalam upaya mengatasi masalah gizi kurang dan gizi buruk, pemerintah telah mengeluarkan kebijakan berupa program pemberian makanan tambahan (PMT) bagi ibu hamil, tetapi pada kenyataannya penerapan program dan keberhasilannya untuk menurunkan masalah gizi masih belum optimal. Upaya penanganan masalah kurang gizi hingga saat ini masih terfokus pada penderita gizi buruk, sementara penderita gizi kurang belum cukup mendapat perhatian. Tidak adanya intervensi gizi bagi penderita gizi kurang dapat memunculkan persoalan kesehatan masyarakat yang lebih serius karena penderita gizi kurang sangat mudah untuk menjadi gizi buruk (6). Efek PMT berdasarkan penelitian sebelumnya terbukti efektif dalam rehabilitasi gizi ibu hamil yang mengalami defisit tingkat kecukupan energi berat. Penambahan 200 - 450 kalori dan 12 - 20 g protein dari kebutuhan ibu adalah angka yang mencukupi untuk memenuhi kebutuhan janin. Meskipun penambahan tersebut secara nyata tidak membebaskan ibu dari kondisi kurang energi kronis (KEK) tetapi bayi yang dilahirkan memiliki berat badan normal (7).

Tindakan pencegahan KEK yang berkaitan dengan konsumsi energi adalah mengkonsumsi makanan yang bervariasi dan cukup mengandung kalori dan protein seperti nasi, ubi, kentang, ikan, telur kacang-kacangan, dan susu sekurang-kurangnya sehari sekali. Bahanbahan tersebut tidak hanya sebagai sumber energi tetapi juga berfungsi sebagai sumber protein. Tiga jenis bahan pangan sebagai sumber protein utama di Indonesia adalah biji-bijian, kacang-kacangan, dan ikan. Jenis produk berupa minuman formula kacang merah, kacang tanah, dan kacang kedelai serta susu mengandung komposisi gizi yang relatif sama, ketiga formula dan susu tersebut hanya berbeda dalam hal rasa $(5,8)$.

Pada saat hamil atau menyusui, diperlukan penambahan makanan atau minuman bergizi untuk memenuhi peningkatan kebutuhan zat gizi. Saat ini, di pasaran terdapat produk minuman bagi ibu hamil dari bahan susu, tetapi harganya cukup mahal. Konsumsi susu yang rendah terkait dengan harga susu yang mahal dan daya beli masyarakat yang rendah. Hal tersebut dapat dimengerti bila konsumsi susu lebih diutamakan untuk kelompok anak-anak balita $(9,10)$. Hasil studi sebelumnya telah dikembangkan minuman formula bergizi berbasis bahan makanan lokal non-susu yang berasal dari kacang-kacangan untuk ibu hamil. Hasil penelitian menunjukkan bahwa minuman formula tersebut mempunyai daya penerimaan yang baik dan mengandung nilai gizi sesuai kebutuhan ibu hamil. Selain itu, formula tersebut dapat dibuat sendiri oleh masyarakat sehingga minuman ini dapat menjadi alternatif konsumsi susu yang dapat dijangkau oleh ibu hamil. Formula yang dikembangkan ada tiga yaitu kacang merah, kacang kedelai, dan kacang tanah dan sebagai kontrolnya adalah formula susu. Formula kacang merah, kacang tanah, dan kacang kedelai rata-rata mengandung energi sebesar 300 kkal; protein $17 \mathrm{~g}$; zat besi (Fe) $13 \mathrm{mg}$; kalsium (Ca) $150 \mathrm{mg}$; magnesium (Mg) $30 \mathrm{mg}$; asam folat $200 \mathrm{mg}$; vitamin A $300 \mathrm{RE}$; vitamin B12 0,2 mg; dan vitamin C $10 \mathrm{mg}$ dalam $300 \mathrm{ml}$ (5). Penelitian tersebut baru terbatas pada eksplorasi formula yang dilakukan di laboratorium pangan, belum dilakukan uji coba pada manusia. Melihat hasil penelitian tersebut yang sangat bermanfaat untuk ibu hamil, maka peneliti ingin mengujikan pada manusia (ibu hamil) apakah ketiga formula tersebut dapat menjadi PMT alternatif pengganti susu pada ibu hamil KEK. Tujuan penelitian ini adalah menganalisis pengaruh pemberian minuman formula kacang merah, kacang 
tanah, dan kacang kedelai terhadap peningkatan status gizi ibu hamil KEK.

\section{BAHAN DAN METODE}

Desain penelitian ini menggunakan rancangan open labeled randomized controlled trial (RCT). Penelitian dilakukan pada ibu hamil kurang energi kronis (KEK) di Kabupaten Sleman yaitu di wilayah Puskesmas Turi, Pakem, Depok II, Ngemplak 1, Ngemplak II, Mlati II, Ngaglik I, dan Ngaglik II pada bulan Januari sampai Maret 2016. Subjek penelitian ini adalah ibu hamil trimester II yang didiagnosis KEK berdasarkan hasil ukuran lingkar lengan atas (LILA) yaitu kurang dari 23,5 cm. Kriteria inklusi meliputi ibu hamil dengan gizi kurang, kehamilan tunggal, dan usia kehamilan trimester II sedangkan kriteria eksklusi yaitu ibu hamil yang mengalami komplikasi kehamilan selama penelitian berlangsung (hipertensi, diare). Perhitungan jumlah sampel dilakukan berdasarkan rumus untuk menghitung jumlah sampel pada uji perbedaan rata-rata dua kelompok dengan tingkat kepercayaan $95 \%$ dan power test $80 \%$ sehingga diperlukan 20 orang untuk setiap kelompok (11). Lebih lanjut, untuk mengantisipasi adanya drop out maka sampel ditambah 10\% sehingga jumlah sampel menjadi 88 orang dengan 22 orang pada setiap kelompok. Pemilihan sampel dilakukan dengan stratified random sampling.

Intervensi dilakukan selama 30 hari dengan pemberian minuman sebanyak $300 \mathrm{ml}$ (1 gelas) yang terbagi menjadi empat kelompok yaitu kelompok perlakuan yang diberi formula kacang merah (A), kacang tanah (B), dan kacang kedelai (C) sedangkan kelompok kontrol (D) diberi minuman susu formula ibu hamil sesuai yang diberikan oleh puskesmas. Ketiga formula tersebut dibuat sendiri oleh peneliti dan hasilnya memiliki kandungan yang sama dengan penelitian sebelumnya yang dilakukan oleh Almasyhuri (5) seperti pada Tabel 1. Pendistribusian minuman formula ini dilakukan setiap hari yaitu peneliti dibantu oleh 8 orang enumerator. Selain itu, enumerator juga bertugas untuk memantau kepatuhan ibu hamil dalam mengkonsumsi minuman formula yang diberikan dengan menggunakan lembar pemantauan.

Variabel bebas adalah minuman formula kacangkacangan dan susu, variabel terikatnya adalah status gizi ibu hamil berdasarkan LILA dan IMT, serta variabel perancu merupakan karakteristik subjek meliputi usia, pendidikan ibu, paritas, dan pekerjaan ibu. Pengukuran indeks massa tubuh (IMT) dihitung dari berat badan (BB) ibu sebelum hamil (kg) dibagi tinggi badan (m) kuadrat. Berat badan ibu sebelum hamil diperoleh dari catatan kohort puskesmas dan dilakukan konfirmasi ulang saat anamnesis ibu hamil. Tinggi badan ibu hamil diperoleh dari catatan kohort puskesmas atau dilakukan pengukuran langsung apabila data tersebut tidak ada dalam catatan kohort puskesmas. Kategori antropometri yang digunakan adalah IMT kurang jika hasilnya kurang dari $18,5 \mathrm{~kg} /$ $\mathrm{m}^{2}$ dan normal jika berada dalam rentang 18,5-25 kg/ $\mathrm{m}^{2}$. Selain itu, dilakukan pengukuran LILA pada ibu hamil dengan menggunakan pita LILA sebanyak 3 kali, kemudian diambil reratanya untuk menentukan LILA ibu hamil.

Instrumen yang digunakan dalam penelitian ini yaitu kuesioner karakteristik subjek dan food frequency questioner (FFQ) untuk mengetahui pola konsumsi makan subjek selama 30 hari terakhir. Asupan makan kemudian dihitung menggunakan program Nutrisurvey untuk mengetahui rerata asupan energi dan protein setiap harinya. Analisis univariat dilakukan untuk mendeskripsikan karakteristik setiap variabel yang diukur dalam penelitian. Variabel perancu meliputi karakteristik subjek dianalisis menggunakan uji Chi-Square. Analisis perbedaan nilai BB dan LILA pada kelompok perlakuan dan kontrol sebelum dan setelah diberikan perlakuan

Tabel 1. Perbedaan kandungan nutrisi antara minuman formula kacang-kacangan dan susu

\begin{tabular}{lccccc}
\hline \multirow{2}{*}{ Formula } & \multicolumn{5}{c}{ Kandungan (\%) } \\
\cline { 2 - 6 } & Air & Energi & Protein & Lemak & Karbohidrat \\
\hline Kacang merah & 80,5 & 96,0 & 5,3 & 3,8 & 11,0 \\
Kacang tanah & 80,1 & 97,0 & 5,5 & 3,7 & 10,4 \\
Kacang kedelai & 79,0 & 101,0 & 5,5 & 3,7 & 13,4 \\
Susu & 85,0 & 100,0 & 7,0 & 1,0 & 12,0 \\
\hline
\end{tabular}


Tabel 2. Karakteristik subjek penelitian

\begin{tabular}{|c|c|c|c|c|c|}
\hline \multirow{2}{*}{ Karakteristik } & Kacang kedelai & Kacang tanah & Kacang merah & Susu ibu hamil & \multirow{2}{*}{$\mathbf{p}^{1}$} \\
\hline & $\mathrm{n}=\mathbf{2 2}$ & $\mathbf{n}=\mathbf{2 0}$ & $\mathrm{n}=\mathbf{2 2}$ & $\mathrm{n}=\mathbf{2 0}$ & \\
\hline \multicolumn{6}{|l|}{ Usia ibu (tahun) } \\
\hline$<20$ & 3 & 0 & 0 & 0 & 0,068 \\
\hline $20-35$ & 14 & 16 & 19 & 15 & \\
\hline$>35$ & 5 & 4 & 3 & 5 & \\
\hline \multicolumn{6}{|l|}{ Pekerjaan ibu } \\
\hline Bekerja & 10 & 9 & 12 & 12 & 0,725 \\
\hline Tidak bekerja & 12 & 11 & 10 & 8 & \\
\hline \multicolumn{6}{|l|}{ Pendidikan ibu } \\
\hline Dasar & 6 & 2 & 3 & 1 & 0,322 \\
\hline Menengah & 11 & 16 & 14 & 14 & \\
\hline Tinggi & 5 & 2 & 5 & 5 & \\
\hline \multicolumn{6}{|l|}{ Paritas (anak) } \\
\hline$\leq 4$ & 20 & 20 & 22 & 20 & 0,123 \\
\hline$>4$ & 2 & 0 & 0 & 0 & \\
\hline
\end{tabular}

${ }^{1}$ uji Chi-Square

dengan menggunakan uji t berpasangan, uji Wilcoxon, dan ANOVA. Analisis peningkatan status gizi pada kelompok perlakuan dan kelompok kontrol dengan mengunakan uji Chi-Square.

\section{HASIL}

\section{Karakteristik subjek penelitian}

Pada akhir penelitian, subjek penelitian mengalami pengurangan jumlah menjadi 84 subjek karena 4 subjek mengundurkan diri (drop out/DO) yaitu kelompok perlakuan sejumlah 2 orang dan kelompok kontrol sejumlah 2 orang. Hal ini tidak mempengaruhi hasil penelitian karena masih dalam standar sampel minimal yang telah ditentukan. Berdasarkan Tabel 2 tampak bahwa usia, pekerjaan, pendidikan, dan paritas tidak menunjukkan hubungan yang signifikan $(p>0,05)$ sehingga tidak perlu dilakukan analisis uji multivariabel untuk menentukan variabel perancu. Tabel $\mathbf{2}$ juga menunjukkan tidak adanya perbedaan karakteristik subjek penelitian antara ibu hamil yang mendapatkan minuman formula kacang-kacangan dan yang mendapatkan susu formula ibu hamil.

\section{Perbedaan antropometri ibu hamil KEK yang diberikan minuman formula kacang-kacangan dan susu}

Tabel 3 menunjukkan tidak terdapat perbedaan yang bermakna antara IMT ibu hamil yang diberikan minuman formula kacang kedelai, kacang tanah, dan kacang merah serta susu formula ibu hamil ( $p>0,05)$. Sebaliknya dengan hasil analisis pada BB dan LILA setelah diberikan intervensi menunjukkan perbedaan secara bermakna $(\mathrm{p}<0,05)$.

\section{Perbedaan status gizi ibu hamil KEK yang diberikan minuman formula kacang-kacangan dan susu}

Subjek penelitian pada kelompok yang diberikan minuman formula kacang tanah mengalami peningkatan status gizi yaitu sebanyak 10 orang menjadi status gizi normal dibandingkan kelompok kontrol yang diberikan susu formula ibu hamil. Hasil analisis menunjukkan bahwa terdapat perbedaan status gizi yang signifikan antara kelompok perlakuan yang diberikan minuman formula kacang tanah dengan kelompok kontrol yang diberikan susu ibu hamil ( $p=0,021)$ (Tabel 4).

Asupan energi dan protein pada ibu hamil KEK yang diberikan minuman formula kacang-kacangan dan susu

Pada hari pertama, rerata asupan energi dan protein masing-masing subjek penelitian masih berada di bawah rerata angka kecukupan energi dan protein yaitu di bawah 1.900-2.200 kkal dan 50-67 g protein. Gambar 1 menunjukkan bahwa asupan protein dari minuman formula kacang-kacangan dan susu masih di bawah angka kecukupan protein ibu hamil yaitu di bawah $67 \mathrm{~g}$. Grafik yang mendekati normal adalah formula kacang tanah 
Tabel 3. Perbedaan ukuran antropometri ibu hamil sebelum dan sesudah diberikan minuman formula kacang-kacangan dan susu

\begin{tabular}{|c|c|c|c|c|c|}
\hline \multirow{2}{*}{ Antropometri } & Kacang kedelai & Kacang tanah & Kacang merah & Susu ibu hamil & \multirow{2}{*}{ p } \\
\hline & $\mathrm{n}=22$ & $\mathbf{n}=\mathbf{2 0}$ & $\mathrm{n}=\mathbf{2 2}$ & $\mathrm{n}=\mathbf{2 0}$ & \\
\hline \multicolumn{6}{|l|}{ IMT $\left(\mathrm{kg} / \mathrm{m}^{2}\right)$} \\
\hline \multicolumn{6}{|l|}{ Pre } \\
\hline Rerata (SD) & $20,19(1,3)$ & $18,51(1,3)$ & $19,26(1,4)$ & $20,11(1,1)$ & $0,009^{2}$ \\
\hline Median & 20 & 19 & 19 & 20 & \\
\hline Rentang & $17-22$ & $15-20$ & $16-21$ & $18-23$ & \\
\hline \multicolumn{6}{|l|}{ Post } \\
\hline Rerata (SD) & $21,24(1,3)$ & $20,89(1,4)$ & $20,39(1,4)$ & $20,84(1,2)$ & $0,560^{2}$ \\
\hline Median & 21 & 21 & 20 & 20 & \\
\hline Rentang & $19-23$ & $19-23$ & $18-23$ & $18-23$ & \\
\hline \multicolumn{6}{|l|}{$\mathrm{BB}(\mathrm{kg})$} \\
\hline \multicolumn{6}{|l|}{ Pre } \\
\hline Rerata (SD) & $49,85(3,2)$ & $46,62(3,4)$ & $47,59(3,8)$ & $48,64(2,05)$ & $0,001^{1}$ \\
\hline Median & 51 & 47 & 47 & 49 & \\
\hline Rentang & $41-53$ & $38-51$ & $41-54$ & $45-52$ & \\
\hline \multicolumn{6}{|l|}{ Post } \\
\hline Rerata (SD) & $52,67(3,2)$ & $51,21(4,0)$ & $50,04(4,4)$ & $50,81(2,6)$ & $0,034^{2}$ \\
\hline Median & 53 & 52 & 50 & 51 & \\
\hline Rentang & $45-57$ & $40-56$ & $43-58$ & $45-55$ & \\
\hline \multicolumn{6}{|l|}{$\operatorname{LILA}(\mathrm{cm})$} \\
\hline \multicolumn{6}{|l|}{ Pre } \\
\hline Rerata (SD) & $22(0,8)$ & $22(0,6)$ & $22(1,0)$ & $22(1,1)$ & $0,001^{1}$ \\
\hline Median & 23 & 23 & 23 & 23 & \\
\hline Rentang & $20-23$ & $21-23$ & $20-23$ & $19-23$ & \\
\hline \multicolumn{6}{|l|}{ Post } \\
\hline Rerata (SD) & $23(0,9)$ & $24(0,7)$ & $23(0,7)$ & $23(1,1)$ & $0,032^{1}$ \\
\hline Median & 23 & 24 & 23 & 23 & \\
\hline Rentang & $21-25$ & $22-25$ & $21-24$ & $20-24$ & \\
\hline
\end{tabular}

${ }^{1}$ uji Chi-Square test; ${ }^{2}$ uji Mann Whitney

Tabel 4. Perbedaan status gizi ibu hamil KEK yang diberikan minuman formula kacangkacangan dan susu

\begin{tabular}{lcccccc}
\hline \multirow{2}{*}{ Status gizi } & Kacang kedelai & Kacang tanah & Kacang merah & Susu ibu hamil & \multirow{2}{*}{$\mathbf{p}^{\mathbf{1}}$} \\
\cline { 2 - 5 } & $\mathbf{n = 2 2}$ & $\mathbf{n = 2 0}$ & $\mathbf{n}=\mathbf{2 2}$ & $\mathbf{n}=\mathbf{2 0}$ & \\
\hline Kurang & 13 & 5 & 15 & 13 & 0,021 \\
Normal & 9 & 15 & 7 & 7 & \\
Total & 22 & 20 & 22 & 20 & \\
\hline
\end{tabular}

${ }^{1}$ uji Chi-Square

dengan jumlah asupan protein mencapai $69 \mathrm{~g}$ pada hari ke-30. Sementara Gambar 2 menunjukkan rerata asupan energi pada kelompok formula kacang tanah setelah diberikan perlakuan selama 30 hari, asupan energi dari makanan yang dikonsumsi berada di atas rerata angka kecukupan yaitu sebesar 2.260 kkal sedangkan pada kelompok susu masih di bawah angka kecukupan energi ibu hamil yaitu di bawah $2.200 \mathrm{kkal}$.

\section{BAHASAN}

Pengaruh pemberian minuman formula kacang tanah, kacang merah, dan kacang kedelai terhadap status gizi ibu hamil

Formula minuman disusun sehingga mengandung zat gizi sesuai dengan kebutuhan tambahan zat gizi untuk ibu hamil. Ketiga formula tersebut dibuat dengan 


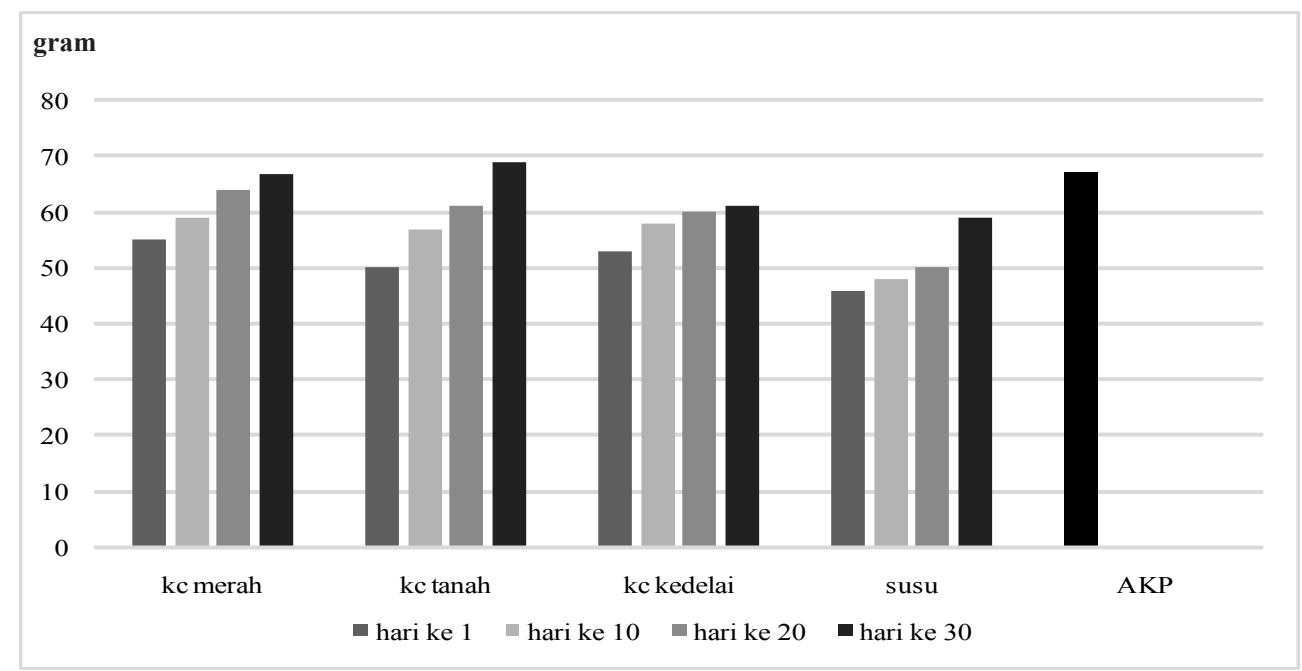

Gambar 1. Grafik asupan protein antara kelompok formula kacang-kacangan dan susu formula ibu hamil dibandingkan angka kecukupan protein (AKP)

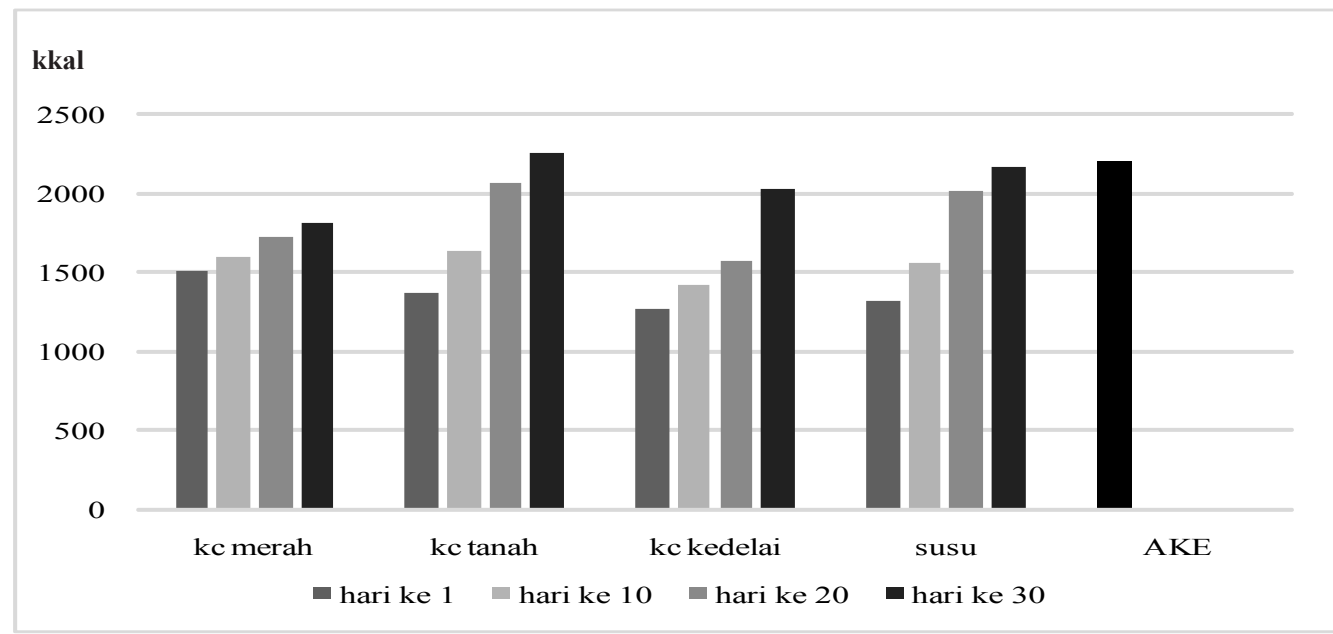

Gambar 2. Grafik asupan energi antara kelompok formula kacang-kacangan dan susu formula ibu hamil dibandingkan angka kecukupan energi (AKE)

komposisi yang sama unsur nutrisinya dengan susu yang biasa dikonsumsi oleh ibu hamil. Bahan-bahan yang digunakan untuk formulasi meliputi sumber protein: kacang merah, kacang kedelai, kacang tanah dan telur; sumber karbohidrat: tepung beras, tepung terigu, tepung garut, gula pasir, dan gula merah; sumber lemak: santan, minyak kelapa; serta perasa alami: sirsak dan jahe. Perlakuan dilakukan selama 30 hari dengan pemberian minuman formula setiap harinya sebanyak $300 \mathrm{ml}$ dan dilakukan pemantauan oleh enumerator.

Hasil analisis menunjukkan adanya perbedaan status gizi yang signifikan pada kelompok formula kacang tanah. Ibu hamil dengan status gizi kurang yang mengalami kenaikan status gizi menjadi normal, paling banyak ditemukan pada kelompok kacang tanah dibandingkan dengan kelompok kacang kedelai, kacang merah, dan kelompok susu. Hal ini berkaitan dengan metabolisme pada masa kehamilan yang meningkat sekitar 15\% (9). Kebutuhan energi untuk menunjang peningkatan metabolisme tersebut sekitar $85.000 \mathrm{kkal}$ untuk 40 minggu masa kehamilan sehingga tambahan rerata kebutuhannya sekitar $300 \mathrm{kkal} /$ hari. Protein sangat diperlukan pada masa kehamilan untuk menunjang pertumbuhan janin dan plasenta. Peningkatan protein 
tubuh selama masa kehamilan sekitar $68,6 \mathrm{~g}$ dan dideposit di jaringan terutama pada trimester ketiga. Berbeda dengan kebutuhan energi, kebutuhan protein ibu yang diperlukan pada masa kehamilan tidak dipengaruhi oleh IMT sebelum hamil, yaitu sebesar 25 $\mathrm{g} /$ hari $(6,7)$.

Lingkar lengan atas adalah salah satu cara untuk mengetahui risiko KEK. Dibandingkan dengan pengukuran antropometri lain, pita LILA adalah alat ukur sederhana dan praktis yang digunakan di lapangan untuk mengukur risiko KEK. Lingkar lengan atas dapat menggambarkan keadaan konsumsi makanan terutama konsumsi energi dan protein dalam jangka panjang. Pengukuran LILA digunakan karena pengukurannya sangat mudah dan dapat dilakukan oleh siapa saja. Departemen Kesehatan menggunakan batasan 23,5 cm untuk menentukan seorang ibu hamil yang berisiko KEK. Apabila ukuran LILA kurang dari 23,5 cm atau berada di bagian merah pita LILA, artinya wanita tersebut berisiko KEK dan diperkirakan akan melahirkan bayi $\operatorname{BBLR}(1,12)$.

Hasil penelitian ini menemukan adanya peningkatan LILA pada semua kelompok, baik kelompok kacang kedelai, kacang tanah, kacang merah, dan susu. Peningkatan paling banyak terdapat pada kelompok kacang tanah dibandingkan dengan kelompok lainnya. Hal tersebut menunjukkan bahwa pemberian minuman formula terutama formula kacang tanah mampu membantu meningkatkan status gizi pada ibu hamil. Namun, intervensi yang dilakukan pada penelitian ini baik pada kelompok perlakuan maupun kontrol sama-sama memberikan dampak yang baik terhadap kesehatan ibu dan janin. Kebutuhan akan susu diperlukan bagi perkembangan janin dan kesehatan ibu, demikian pula minuman formula kacang dapat menjadi alternatif pemenuhan kebutuhan makanan bagi ibu hamil selain susu. Hasil penelitian ini sejalan dengan penelitian sebelumnya yang telah menemukan formula berbahan non-susu yang dibuat khusus bagi ibu hamil dan menyusui yang dapat membantu ibu dalam mengambil keputusan untuk memenuhi kebutuhan akan nutrisi setiap hari (5).
Pengaruh pemberian minuman formula kacang tanah, kacang merah, dan kacang kedelai terhadap asupan energi dan protein ibu hamil

Diperlukan tambahan makanan atau minuman bergizi untuk memenuhi kebutuhan zat gizi makro dan mikro pada saat hamil (10). Kandungan zat gizi dari bahan yang digunakan untuk formulasi telah dihitung berdasarkan daftar komposisi bahan makanan sehingga mengandung zat gizi sesuai dengan kebutuhan tambahan untuk ibu hamil, yaitu mengandung $300 \mathrm{kkal}$, protein 17 $\mathrm{g}$, asam folat $200 \mathrm{mg}$, dan vitamin C $10 \mathrm{mg}$ dalam $300 \mathrm{ml}$ minuman formula. Beberapa faktor yang dipertimbangkan dalam pemilihan jenis produk adalah bahan produk sudah dikenal dan memiliki cita rasa yang baik sehingga disukai dan bisa diterima oleh masyarakat secara luas, praktis, memiliki daya simpan yang relatif lama, dan mudah dalam penyajiannya, serta aspek lain yang dipertimbangkan adalah komposisi gizi produk. Jenis produk yang diberikan pada penelitian ini berupa minuman formula kacang merah, kacang tanah, dan kacang kedelai serta susu. Pemberian ketiga formula dan susu tersebut hanya berbeda dalam hal rasa, tetapi komposisi gizinya relatif sama.

Hasil penelitian ini menunjukkan bahwa peningkatan asupan energi pada kelompok formula kacang tanah lebih besar dibandingkan dengan kelompok kacang kedelai, kacang merah, dan susu ibu hamil. Terdapat perbedaan yang signifikan antara sebelum dan setelah diberikan intervensi. Asupan energi setiap minggu pada kelompok perlakuan dan kontrol mengalami peningkatan dengan rentang peningkatan sebesar 1.9002.200 kkal. Asupan energi yang masih defisit menjadi salah satu penyebab utama tidak bertambahnya berat badan sehingga target penambahan berat badan sebesar $500 \mathrm{~g} / \mathrm{kg}$ BB per minggu tidak tercapai (13).

Pada masa kehamilan, metabolisme mengalami peningkatan sehingga kebutuhan energi dan protein serta zat gizi lainnya juga meningkat. Peningkatan berat badan selama kehamilan merupakan indikator untuk menilai kesehatan ibu dan janin. Pola penambahan berat badan yang kontinyu lebih penting daripada total penambahan berat badan itu sendiri (14). Penelitian yang dilakukan di Puskesmas Seyegan menyebutkan 
bahwa kejadian KEK pada ibu hamil di daerah penelitian dipengaruhi oleh pengetahuan ibu tentang jumlah makanan dan pengetahuan tentang anggota keluarga yang diprioritaskan untuk memperoleh makanan. Selain itu, diperoleh informasi bahwa KEK dipengaruhi oleh jumlah dan pola konsumsi asupan protein sedangkan konsumsi lemak dalam makanan tidak berhubungan bermakna dengan status KEK (15). Langkah yang harus diambil untuk mengatasi kekurangan gizi adalah meningkatkan kualitas konsumsi pangan mencapai tingkat konsumsi energi sebesar $2.200 \mathrm{kkal} / \mathrm{kapita} / \mathrm{hari}$ dengan tetap memperhatikan kualitas dan kuantitas makanan yaitu dengan mengkonsumsi aneka ragam pangan. Belum terpenuhinya kebutuhan tubuh akan energi menyebabkan tidak efektifnya konsumsi protein yang dilakukan karena sebagian dari zat gizi protein yang dikonsumsi akan diubah menjadi energi mengalahkan fungsi utamanya sebagai zat pembangun dan pemelihara sel dan jaringan tubuh. Agar zat gizi protein dalam tubuh dapat berperan sebagaimana mestinya maka sebaiknya kebutuhan tubuh akan energi dipenuhi terlebih dahulu (16).

Penanggulangan masalah gizi dan kesehatan untuk meningkatkan kualitas sumber daya manusia, paling tepat dilakukan pada masa menjelang dan saat prenatal. Alasan yang mendukung yaitu perkembangan otak dimulai pada masa kehamilan, ibu hamil yang menderita defisiensi zat gizi berisiko lebih besar untuk melahirkan bayi dengan BBLR. Selanjtunya, bayi BBLR berisiko lebih besar untuk meninggal pada usia satu tahun dan jika mampu bertahan hidup akan berisiko lebih besar untuk menderita penyakit degeneratif pada usia yang lebih muda dibandingkan dengan bayi yang lahir dengan berat normal. Bayi BBLR juga dapat menyebabkan kekerdilan bila kondisi kesehatan dan makanan tidak mencukupi selama perkembangan setelah kelahiran. Dampak yang lebih luas yaitu menurunkan kecerdasan, mengganggu pertumbuhan, imunitas rendah, dan morbiditas serta mortalitas meningkat dengan munculnya penyakit degeneratif saat dewasa. Memperhatikan dampak kurang gizi yang sangat luas, maka diperlukan upaya penangganan gizi ibu hamil. Berkaitan dengan hal tersebut telah dilakukan intervensi pemberian makanan tambahan pada ibu hamil (7). Hasil penelitian ini diharapkan dapat memberikan informasi tentang minuman tambahan berbasis pangan lokal kacang-kacangan untuk meningkatkan status gizi ibu hamil sehingga hasil penelitian ini dapat dijadikan sebagai masukan bagi dinas kesehatan dan petugas kesehatan di Puskesmas wilayah Kabupaten Sleman Yogyakarta dalam melaksanakan program perbaikan gizi ibu hamil. Namun demikian, penelitian ini memiliki beberapa keterbatasan yaitu penelitian hanya dilakukan selama 30 hari. Hasil penelitian yang diperoleh akan lebih maksimal jika dilakukan dengan waktu yang lebih lama.

\section{SIMPULAN DAN SARAN}

Terdapat pengaruh pemberian minuman formula kacang merah, kacang tanah, dan kacang kedelai terhadap status gizi ibu hamil. Pemberian formula kacang tanah berpengaruh signifikan terhadap status gizi jika dibandingkan susu formula ibu hamil sedangkan formula kacang merah dan formula kacang kedelai tidak berpengaruh secara signifikan. Pemberian minuman formula kacang tanah dapat digunakan sebagai alternatif model intervensi untuk meningkatkan status gizi ibu hamil karena terbukti secara bermakna meningkatkan asupan energi dan memperbaiki status gizi kurang pada ibu hamil.

Pemberian minuman formula kacang-kacangan menggunakan potensi sumber bahan makanan lokal dapat diterapkan sehingga petugas kesehatan/petugas gizi dapat memberdayakan kader dan masyarakat/ibu balita dalam membuat formula tersebut dan menggali potensi sumber bahan makanan lokal yang tersedia untuk diolah sebagai makanan/minuman tambahan yang terukur kandungan gizinya. Perlu penelitian lebih lanjut dengan desain mix method untuk mendapatkan data yang lebih mendalam.

\section{Pernyataan konflik kepentingan}

Penulis menyatakan tidak ada konflik kepentingan dengan pihak-pihak yang terkait dalam penelitian ini.

\section{RUJUKAN}

1. Sanjaja. Resiko kurang energi kronik (KEK) pada ibu hamil di Indonesia. Gizi Indonesia 2009;32(2):128-38.

2. Kementerian Kesehatan RI. Pedoman gizi ibu hamil dan pengembangan makanan tambahan ibu hamil berbasis pangan lokal. Jakarta: Direktorat Bina Gizi Masyarakat; 2010. 
3. Badan Perencanaan Pembangunan Nasional. Rencana aksi nasional pangan dan gizi 2011-2015. Jakarta: BAPPENAS; 2011.

4. UNICEF. The state of the world's children. New York, US: Oxford University Press; 1998.

5. Almasyhuri, Imanningsih N, Purawisastra S, Affandi E, Nurjanah N. Pengembangan minuman formula ibu hamil dan meneteki berbasis bahan lokal non susu. Penel Gizi Makan 2008;31(1):42-50.

6. Falciglia GA. Optimal weight gain. In: Lammi-Keefe CJ, Couch SC, Philipson EH (eds). Handbook of nutrition and pregnancy. Nutrition and Health. Totowa, NJ: Humana Press; 2008.

7. Prihananto V SA, Riyadi H, Palupi S. Pengaruh pemberian makanan tambahan terhadap konsumsi energi dan protein ibu hamil. Jurnal Gizi dan Pangan 2007;2(1):16-21.

8. Rina Yenrina Y, Deddy Muchtadi. Pengolahan dan penerimaan produk kedelai pada rumah tangga di perkotaan dan pedesaan Pulau Jawa Indonesia. Jurnal Gizi dan Pangan 2006;1(1):36-43.

9. Ritchie LD, King JC. Nutrient recommendations and dietary guidelines for pregnant women. In: Lammi-Keefe CJ, Couch SC, Philipson EH (eds). Handbook of nutrition and pregnancy. Nutrition and Health. Totowa, NJ: Humana Press; 2008.

10. Ali Khomsan FA, Eddy SM. Pengetahuan, sikap dan praktek gizi ibu peserta posyandu. Jurnal Gizi dan Pangan 2009;4(1):33-41.

11. Sopiyudin D. Besar sampel dan cara pengambilan sampel dalam penelitian kedokteran dan kesehatan. Jakarta: Salemba Medika; 2013.

12. Supariasa IDN, Ibnu F. Penilaian status gizi. Jakarta: EGC; 2001.

13. AzwarA. Kecenderungan masalah gizi dan tantangan di masa dating. Pertemuan advokasi program perbaikan gizi menuju keluarga sadar gizi; 2004; Hotel Sahid Jaya, Jakarta.

14. Rasmussen KM, Yaktine AL, editors. Weight gain during pregnancy: reexamining the guidelines. Washington (DC): National Academies Press (US); 2009.

15. Khaidar. Hubungan kekurangan energi kronik pada ibu hamil dengan berat badan lahir bayi di wilayah Puskesmas Seyegan Kecamatan Seyegan Kabupaten Sleman Yogyakarta. Yogyakarta; Fakultas Kedokteran UGM: 2005.

16. Hanafie R. Peran pangan pokok lokal tradisional dalam diversifikasi konsumsi pangan. J-SEP 2010;4(2):1-7. 